\title{
Tierra roja
}

Miguel Ahumada Cristi*

Delante del brillo oscuro de tinta y mate

Descansa la memoria triste, en agua y pez

Oh, soledad, oh, voluntad

Llamo a la mano amiga en el dolor.

La palabra viste remansos de hojas tibias

El viento fecunda el río en la verdad

Oh, mi memoria, oh, bendición

El cóndor se había olvidado, ya volvió.

Los lunes de trenes viejos sin desfilar

Los bailes que no se asustan de tú y de mí

Oh, soledad, oh, perdición

El Ypê está florecido, nadie llegó.

Las hojas de otoño caen sin un sonido

El aire no canta nada, la nada ríe

Oh, cordillera, oh, bravo azul

Los rostros ya no se encuentran, nadie besó.

Las mesas del patio viejo no tienen sombra

El patio ya no es motivo, nadie abrazó

Oh, soledad, oh, perdición

Las sillas de nada sirven, no hay tú ni yo.

\footnotetext{
* Miguel Ahumada Cristi es chileno. Hace vida en Brasil desde 2012. Actualmente es Profesor e Investigador en la Universidad Federal de la Integración Latinoamericana, UNILA. Además, es Músico y Director del Grupo Musical Marichiwew - Cantos Latinoamericanos, una acción de extensión universitaria. Ha publicado dos libros de poesía, independientes, en Santiago de Chile. Un tercer libro, de poesía infantil, llamado "Barquito de papel", está siendo ilustrado por el artista Yuri Amaral, y se publicará en 2021.
}

Revista Moara, n. 56, vol. 1, ago-dez 2020 ISSN: 0104-0944 
El tiempo no da sorpresas, todo es antiguo

Los héroes ya no se mueren, el temor

Oh, mi memoria, oh, tu dolor

La mañana tiene nombre, nadie nombró.

América tiene espaldas de tierra roja

Su tronco viene minando los pies de angustias

Oh, el sentir, oh, el vivir

De cuando en cuando te miro, y crezco allí.

Los verdes sin animales dejan recuerdos

Las armas son desagravio a mi prisión

Oh, llanura, oh, musgo heraldo

Las aguas caen del cielo, nadie regó.

Entre espejos impávidos viene la historia

Las letras que al fin la narran, se escapan solas

$\mathrm{Oh}$, metales, oh, fronteras

Lo simple viene cantando, nadie escuchó.

No quiero que los caídos no se recuerden

Cuando el instante oscuro cubra miradas

Oh, si volvieran, oh, con tú y yo

La golondrina americana sería un dios.

Revista Moara, n. 56, vol. 1, ago-dez 2020 ISSN: 0104-0944 